\title{
The Market for Inventions: Experimental Aircraft Engines*
}

\author{
Mark Harrison**
}

\begin{abstract}
The secret of the Soviet defense industry's successes began with research and design. The institutions of a command system were poorly equipped to direct the research process. The officials who had to fund and manage research started from a set of unknowns: they did not know how technology would evolve, or where were the best places to look for breakthroughs; worse still, they knew less about science and technology than the designers and so were not well placed to evaluate the personal and team qualities of the people they were supposed to manage. Despite this the process worked. This paper looks at the Soviet search for new techniques of aircraft propulsion in the 1930s and 1940s, which created a "market for inventions."
\end{abstract}

The second quarter of the twentieth century witnessed an astonishing revolution in military technology. World War I saw the beginnings of motorized warfare; aircraft were used in combat and the first tanks appeared. By the end of World War II they were the primary armament of continental warfare. The interwar period also saw the scientific breakthroughs that would eventually lead to radar, guided missiles, and atomic weapons.

The Soviet economy was large but poor, and it was particularly poor in the scientific and information infrastructure that made the other powers rich. Despite this, the Soviet defense industry was invariably close to the forefront of global

* This paper appeared as a chapter in Guns and Rubles: The Defense Industry in the Stalinist State, pp. 210-229. Edited by Mark Harrison. New Haven, CT: Yale University Press. Yale-Hoover Series on Stalin, Stalinism, and the Cold War.

** Mail: Department of Economics, University of Warwick, Coventry CV4 7AL, UK. Email: mark.harrison@warwick.ac.uk. I thank the Leverhulme Trust, the British Academy, and the University of Warwick Research and Innovations Fund for financial support of my research on "Invention, Imitation, and the Birth of Soviet Aerospace"; the University of Warwick for study leave; and the staff of the State Archive of the Russian Federation (GARF), the Russian State Economic Archive (RGAE), and the Russian State Military Archive (RGVA) for access to documents. 
developments. Behind the scenes there was a good deal of emulation of foreign progress and outright copying; copying, however, was rarely as simple as might appear at first sight since what could not be copied was the "how-to" knowledge of materials and working them that gave rise to precision and reliability. Technologically, therefore, we are looking at a success story.

In writing the economic history of the underlying processes, hindsight is very useful since it tells us that the successes actually happened. To understand how they happened, however, how they were organized and how the decisions were made that brought them about, there comes a point where we must throw hindsight away; we must try to see the process through the eyes of contemporaries who did not know where their actions would lead. When we do this, we find that managing technological change is quite similar to managing mobilization planning (Chapter 5) in two respects. First, those responsible faced huge uncertainty about what they were planning for. Second, everyone had an axe to grind.

The uncertainty was over the most promising directions of technological development. There were many possibilities of which only a few would prove fruitful; as the economic historian Joel Mokyr (1990: 176-77) has pointed out, the many inventions that failed were part of the cost of success. The specialists themselves did not appear to suffer from this uncertainty, however: they were usually certain about the right way to go forward, or behaved as if they were certain. The problem was that they did not agree among themselves, and could not all have been right at the same time. In aircraft propulsion in the 1930s, for example, there appear to have been at least four groups. One group believed that the future lay with rockets, so they designed rocket aircraft. Another group believed, equally strongly, that the rocket engineers were fools, and that the future lay with the jet engine. A third group, about which history has almost forgotten, believed that the technology of steam turbines, already tried and tested in naval propulsion and power generation, could be applied to aviation. A fourth group thought that the first three groups were all dreamers, and the practical way forward was to concentrate on improving the existing reciprocating engines. Stalin, who took a keen personal interest in the modernization of the Red Army's weaponry, warned the aircraft designer Aleksandr Iakovlev (2000: 501):

A designer is a creative worker. Like the painter of a picture or the writer of a literary work, the product of a designer's or scholar's creativity can be successful or unsuccessful. The only difference is that from a picture or verse you can tell the author's talent right away. ... With a designer it's more complicated: his design can look very attractive on paper, but final success or failure is determined much later as a result of the work of a numerous collective and after the expenditure of substantial material means ... Most designers get carried away with themselves and are convinced of their own and no one else's righteousness; on the basis of an overdeveloped self-regard and the mistrust that is characteristic of every author they tend to attribute their own failures to prejudice against themselves and their creations. 
With hindsight we can see that, from the point of view of fighting the coming war, the fourth group of conventional improvers was right, since none of the others contributed anything practical to the Soviet war effort. We also see that the third group, the steam turbine engineers, was marching confidently into a dead end. Using a longer time horizon, one that extends beyond 1945, the first two groups will each be found to have made a valid contribution, but the rocketeers' was valid only by accident: the rocket was not the answer for aviation, and would turn out to solve the problem of strategic bombardment only because of the atomic bomb which had not yet been invented. The jet engine, in contrast, would dominate military and commercial aviation into the next century; its designers expected this and said so at the time; as it happens, therefore, they were the ones who were proved right in the long term. Those responsible for directing and funding research and development (R\&D), in contrast, knew nothing of this. Their first handicap was that they did not have a clear idea of the appropriate time horizon over which to demand results; they did not know whether there would be a war or how long it might last. Second, they were also less well qualified than the specialists themselves to judge competing claims. What were they supposed to do? Given limited ruble funding of military research and many competing claims on it, they tended to ration it out across a wide range of projects, giving nearly everyone a little and no one as much they wanted.

The axes being ground were the special interests of the rival parties. Each declared that their own motivation was unselfish and based on the interests of the collective: they had no private interest, only the interests of the party and the government at heart. It was those who stood in their way that were selfishly motivated. Economic reasoning suggests, however, that each had a clear private interest at stake, and that this would have important consequences for the efficiency of resource allocation.

For illustration, suppose that people generally differ in the amount of talent they have, and this decides how productive they are; for simplicity, they can be talented or untalented. In most occupations what kind they are would quickly become obvious, and as a result two salary levels would be established, high (for talented people) and low (for the untalented). But not all work is like that. Military invention provides cases of projects that lasted many years before coming to fruition or being closed down. In long term projects it may not become apparent how talented or productive are the employees until the project is finished; in the interim, everyone looks alike. Meanwhile, all must be paid the same, regardless of true talent. What are the likely consequences?

For aircraft propulsion between the wars, the Soviet authorities had a budget from which they could choose to employ many or few designers. Other things being equal, the more designers they employed, the greater their chance of final success. But other things would not be equal. The number employed would influence the average salary paid: the greater the number, the lower the salary.

Suppose the funding authority paid the average salary in the economy: the average would be above the low rate paid to untalented people, and these would be attracted into military research. Effectively, military R\&D would become a field where the untalented could gain a temporary salary premium while hiding 
their lack of talent. But the average would also be below the rate payable to talented people elsewhere, and many would leave military projects in response. Some would stay: those with sufficient inner motivation to compensate for the financial sacrifice. But talented people, even if some do not care about themselves, are also likely have families and dependents, and this means that few can ignore pay disadvantage completely.

If the authorities responded by cutting back employment and raising salaries above the rate for talent, they would win more talented designers back into the field but the premium on the untalented would now be exceptionally high and these would crowd into employment in even greater numbers. Simultaneously, those seeking work would rise while those obtaining it would fall; the talented minority would be squeezed by the untalented crowd, and this would risk more damage to the general chances of final success. This is the problem of adverse selection: there were two types of project, good and bad; because the authorities could not tell them apart, bad projects would tend to drive out good ones. ${ }^{1}$ Finally, although technically ignorant, the authorities were not economically stupid and rationally mistrusted the designers that stayed in the market for this very reason.

Even in the context of a highly centralized command economy, it is impossible to describe this process without using the terminology of markets. The first part of this chapter describes the "market for inventions" in more detail: who were the actors, what it covered, and how decisions were made in it. Part 2 looks at the designers and their active role in promoting research and securing funding. In Part 3 we look at the market from the point of view of the funders, who faced the difficult problem of deciding when to discontinue funding for unsuccessful research. Part 4 concludes.

This chapter is about the market for experimental aeroengines. The market was opened in 1932 and closed down in 1946. I do not try to narrate the story of what happened in the market in any detail. ${ }^{2}$ The early and mid-1930s saw a wideranging exploration of alternatives. Soviet designers worked on lines parallel to progress in other countries, but in isolation from it and lagging behind by a margin that was often narrow. As war approached, the authorities' enthusiasm for radically new long-term developments waned and their interest became narrowly focused on quick results. Research on steam turbines was recognized to be going nowhere and came to an end. Interest in jet and rockets revived during the war, magnified by the appearance of German V2 rockets and German and British jet

${ }^{1}$ George Akerlof (1970) argued that if sellers offer second-hand automobiles that are either of bad quality ("lemons") or good, and sellers know the quality of what they offer but buyers do not know the quality of what they buy, buyers will offer an average price that will be attractive only to the sellers of bad automobiles; it will be too low for sellers of good automobiles to wish to sell, and bad automobiles will drive out good ones. This is one of the propositions for which he shared the 2001 Nobel Prize for Economics.

${ }^{2}$ See Harrison (2000, 2003, and 2005). For a standard account written before the archives see Holloway (1982). 
aircraft and, at the war's end, the Allied forces' seizure of technological trophies in occupied Germany. These developments drove away the uncertainties, forced the resolution of differences, and led to the closing down of the market. By 1946 Soviet specialists were working to Stalin's order on German rockets and British and German jet engines. They quickly brought them into production and also began to improve them. Their ability to so was an achievement in its own right; it would hardly have been possible without their background of independent endeavor.

\section{The Market for Inventions}

\section{The Players}

There were four main sets of players in the Soviet market for inventions: a Dictator, the Army, Industry, and the Designers. Stalin presided over the market process through the committees and commissions responsible for defense matters described above in Figure 3.2; he also took an active personal interest. Strategic decisions were taken at this level that framed the market for inventions by defining government funding priorities and authorizing major organizations to enter or leave the market; for example, on July 4, 1932, the defense commission issued the decree that first approved initiatives in steam and gas turbines and rocketry; subsequent decrees taken at a similar level through the 1930s and 1940s created new research institutes and gave priority to specific projects (Danilov 1981: 71).

<Figure 8.1 here. $>$

The result was a quasi-market, rather than a real market, as we have defined them in Chapter 3. The market process was played out by actors representing the Army and Industry; these are illustrated in Figure 8.1. The Army's chief role, fulfilled by the defense ministry as consumer, was to disburse much of the funding for military research. Most commonly the Army contracted out inventive activity to the research institutes and design bureaux of Industry. The most important, and interesting, direction of the flow of funding therefore followed the solid arrows from the Dictator through the Army to Industry and Industry's Designers. As we shall see, however, there were also subsidiary flows, shown in the figure as dashed arrows: the Army carried out some research and design activity in-house, and Industry also funded some R\&D on its own account.

Normally, the Army and Industry independently formulated operational plans for research and experimentation that were then coordinated through a contracting process. The most important planning horizon was annual. The Red Army had an annual plan for the development of military inventions most of which it contracted out to industrial organizations through the quasi-market for inventions. Industrial ministries also had their own R\&D plans, for example the annual plan for experimental aeroengines to be carried out by the institutes and bureaux of the 
aviation industry, part of which was made up by contracts accepted from the Red Army.

These arrangements imposed the following structure on competition among designers. There were many designers and many design organizations. Since projects had to have a home, the industrial design bureau was the main vehicle for this competition. Designers competed for funding from a few potential sources. In principle the defense industry monopolized the market but in practice its monopoly was sometimes threatened by other parties: other industries with sideline interests that led them to seek diversification, military men interested in the scope for vertical integration, and the Dictator who could revoke the delegation of his powers to the market at any time and impose direct control under the NKVD.

As the principal funder the Red Army made various attempts to by-pass the quasi-market for inventions and substitute itself for Industry. Military research institutes and design bureaux carried out some in-house research. During his time in charge of the procurement of Red Army equipment marshal Mikhail Tukhachevskii, executed in 1937, was an eager modernizer and an enthusiast for rocket armament and aviation; he was particularly keen on keeping it under direct military control (Holloway 1982: 321). The NKVD also intervened from time to time by seizing the designers and managing them on a prison basis (Albrecht 1989: 133-35; Starkov 2000: 255-60; Mukhin 2004a). The owner of factory no. 16 in Kazan', for example, was the ministry for the aircraft industry, but its aeroengine design bureau was a prison bureau staffed by prisoners and run by the NKVD fourth special department.

\section{Scale and Scope}

Between 1932 and 1946 there were, in total, roughly 30 major projects in new kinds of aviation propulsion. It is a rough count based on the activities of major designers, institutes, and bureaux recorded in the plans, reports, and memoranda of the ministries of defense, internal affairs, and the heavy, defense, ammunition, and aircraft industries. ${ }^{3}$ The count is likely to be incomplete to the extent that records were incomplete and some activity was unplanned; but it has the great advantage of being based on records that were compiled without hindsight, the point being that hindsight tends to lose sight of the false starts and failures that were an essential part of the invention process.

The breakdown of these projects may surprise the reader. There were seven major projects in rocket research; these include the rocket engines and experimental aircraft of the future Soviet chief missile designers Vladimir Glushko and Sergei Korolev whose work remained heavily focused on aviation until after the war. Because of their future importance for the postwar missile and space races western analysts and historians have given exhaustive attention to

${ }^{3}$ These and other figures that follow are found by adding together the numbers of research and design projects in steam turbines from Harrison (2003) with those in jet and rocket propulsion from Harrison (2005). 
these projects. ${ }^{4}$ But this was actually the smallest group of projects. More was spent elsewhere.

The next group was the 10 major projects in steam turbine development. It may be unexpected to find that so much serious effort went into the unsuccessful attempt to build steam aircraft. But it is only surprising with hindsight. As long as the problem of a reliable, efficient, long-range, high-altitude successor to the reciprocating engine remained unsolved, it was sensible to go on looking at all potential answers; the 1930s saw similar projects in Britain, France, Germany, and the United States, a fact of which the Soviet authorities were well aware. ${ }^{5}$ It is likely, however, that more was spent on this line of research in the Soviet Union than in the rest of the world put together.

The largest group was the 13 jet engine projects. These were highly varied and only two would result in workable engines by the end of our period: the first Soviet turbojet and turboprop engines, designed by Arkhip Liul'ka and Vladimir Uvarov respectively. Most of the other projects involved either simple ramjets, that could boost a conventional aircraft only when it was already flying at speed, or "hybrid" attempts to work around the most daunting technological challenges of the turbojet. The usual workaround was to use a conventional reciprocating engine rather than a gas turbine to supercharge the jet engine's air intake; the Italians famously flew a hybrid jet aircraft of this type, the Caproni-Campini N1, from Rome to Milan in 1940.

<Figure 8.2 here.>

Figure 8.2 shows how the investments in R\&D may have mounted up. The unit of measurement is a "major project-year"; the measure is arbitrary, but perhaps no less arbitrary than a monetary scale. The figure shows, on this measure, that knowledge and experience built up most rapidly for steam turbines until 1939 when, at 16 project-years, the authorities determined that this was a dead end and they did not need to find out any more. Jet engine research did not catch up until 1942 but then accelerated, reaching 44 project-years by 1946 . Even by 1946 , rocket research had barely caught up with the prewar effort in steam turbines.

<Figure 8.3 here.>

${ }^{4}$ See for example Ordway and Sharpe (1979); Holloway (1982); Albrecht (1993); and Siddiqi (2000, 2003, and 2005).

${ }^{5}$ The projects outside the Soviet Union were surveyed for German readers by Knörnschild (1941) and for the British in wartime by Smith (no date: 36-40). A memorandum of February 28, 1937 (RGAE, 8328/1/919, 77) indicates the extent of Soviet prewar knowledge of these foreign projects, which was fairly complete and mostly correct but lacked technical detail. 
There was considerable project turnover, and this is of interest because we would like to know more about how projects came to be seen as promising enough to win start-up funding, and how they came to be terminated as failures. Figure 8.3 illustrates the turnover for experimental aeroengine projects in the aggregate. In most years there were a couple of start-ups, sometimes one, sometimes three. Terminations were less frequent and were more bunched. A few events lie behind the irregularities seen in the figure. The Great Terror of 1937/38 led to the arrest of some famous rocket designers including Glushko and Korolev, and a complete break in rocket research, but since projects in progress were few there was little influence on the figures in the chart. In 1939 there was a major shift in emphasis from steam to gas turbines; this is reflected in both the high casualty rate of 1938 and 1939 which brought steam turbine research to an end, and the large number of fresh start-ups in 1939. The outbreak of the war in June 1941 led to a temporary suspension of jet research from which no quick payoff was expected and a turn back to rocket aviation which was thought at the time to be nearer to a practicable high-speed interceptor.

As a fraction of national resources, the sums involved were tiny. The 1937 annual plan for the most important research organization in rocketry envisaged 476 staff, including 118 engineers, with a value of work of 4.5 million rubles. ${ }^{6}$

But three fifths of its work was unrelated to aviation. ${ }^{7}$ In contrast the overall value of equipment orders for the army and navy in the same year was 5.7 billion rubles (Davies and Harrison 1997).

\section{Effort and Reward}

Those who worked in the market for inventions could expect to be modestly better off than others. The average monthly pay of specialist ("engineering and technical") workers at research institute no. 3 (NII-3) for ammunition in the first quarter of 1941 was 818 rubles, roughly two and a half times the average industrial wage of $1940 .^{8}$ More detail is available for the 250 "management and administrative" staff of Liul'ka's experimental aircraft factory no. 165 in August 1946; this category included everyone from the chief designer $(6,000$ rubles a month) to the floor sweepers in the labs (200 rubles). The median monthly wage was 875 rubles, compared with 626 rubles for the average industrial wage in December of that year (Filtzer 2002: 235). It was enough to staff the factory fairly fully; there were only eight vacant posts, of which seven offered less than 400 rubles. ${ }^{9}$

${ }^{6}$ RGAE, 8162/1/16: 4 (no date but about February 1937). This was the Jet Propulsion Research Institute (RNII).

${ }^{7}$ RGAE, 8159/1/6: 74 (December 1936).

${ }^{8}$ RGAE, 8162/1/449, 87 (April 10, 1941).

${ }^{9}$ RGAE, 8044/1/3079, 82-91 (August 27, 1946). 
Basic pay was just the start; there were plentiful supplements and incentive payments. The director of research institute no. 3 , for example, was said to have received 19,250 rubles on top of his salary in 1939 and the first half of $1940 .^{10}$ The evidence is piecemeal and we have no clear picture of how such sums were fixed or allocated. Documents suggest that officials tended to seek approval for making side-payments to mark significant reorganizations, achievements, and anniversaries. In November 1933, for example, the chief of the Red Army administration for military inventions asked for 2,500 rubles for bonuses to mark the first Soviet liquid fuelled rocket and the establishment of the new jet propulsion research institute (RNII). ${ }^{11}$ In July 1940 the director of research institute no. 3 asked for his most outstanding staff, not named, to be given medals to mark the successful exploitation of its rocket shells in combat against Japan and Finland. ${ }^{12}$ In July 1947, armament minister Ustinov and NKVD chief Kruglov wrote to Stalin for permission to award commemorative decorations to the former "enemies of the people" working in the prison design bureau no. 172 (OKB-172) to mark its tenth anniversary. ${ }^{13}$ What is striking is the lack of rules and guidelines; everything was argued ad hoc. To put it another way, it seems possible that any excuse would have done.

The lack of rules was a source of danger to those making or approving such requests, which could easily be made to look corrupt. Prewar investigations, for example, redefined many instances of side payments and awards as unjustified after the event. A finance ministry audit of defense industry research establishments in 1938 found that the central institute for aeroengineering (TsIAM) was running no less than 19 separate incentive schemes on which it had spent 1.2 million rubles in 1937 along with another 200,000 rubles on rest cures and sickness benefits. ${ }^{14}$ An audit of research institute no. 3 two years identified a loot chain through which the director not only made "unjustified" side payments to himself but also used incentive schemes to pay off his colleagues and bosses. ${ }^{15}$ The point is not whether such payments were truly unjustified, but that the lack of rules at the time leave them impossible for us to judge after the event.

Finally, of significance equal to or greater than cash in a shortage economy was the privileged consumer provisioning available to those whose jobs gave them the right to a Moscow residence permit. In the 1930s the aircraft industry

${ }^{10}$ RGAE, 7516/1/692, 3 (November 21, 1940).

${ }^{11}$ RGVA, 34272/1/146: 145 (Terent'ev to Tukhachevskii, November 16, 1933).

${ }^{12}$ RGAE, 8162/1/306: 186-187 (Slonimer to Sergeev, July 22, 1940).

${ }^{13}$ GARF, 9401/2/170: 213-228 (July 13, 1947).

${ }^{14}$ RGAE, 7515/1/379: 134-137 (April 19, 1938).

${ }^{15}$ RGAE, 7516/1/692: 1-7 (November 21, 1940). 
opened a number of new factories in the provinces, some near Moscow, some thousands of kilometers to the east. Mukhin (2004b) has shown that Moscowbased aviation specialists could be persuaded to leave the capital only with great difficulty, and then only when the ministry gave a written guarantee of their future right of return. Their reluctance was the same, regardless of whether "the provinces" were on the Pacific coast or only just outside the Moscow city limits.

\section{Who Drove the Market?}

Although it looked as if planned from above, the quasi-market for inventions was actually driven by the designers. The stereotype of a command system might lead one to expect the dictator to have controlled the market by simultaneously issuing funds to the Army and orders to Industry, leaving only a small role for the subsequent negotiation and exchange of contracts for the work to be carried out. As Andrei Markevich has shown in chapter 4, something like this was the intention in the planning of the defense industry's current production, although it was not and could not have been implemented perfectly. As far as the planning of inventions is concerned, this model was not an option at all. The difficulty was that, given the uncertainty surrounding the future of technology, Stalin did not and could not know what orders to give in the first place. The designers knew better, and the dictator had to adapt to this reality. This applied even to the highest-level strategic decisions, which seem to have been strongly influenced by lobbying from below.

Not surprisingly, successful designers had to be active lobbyists; they were what Donald Mackenzie (1996: 13) has called "heterogeneous engineers," capable of building networks as well as machines, and reshaping organizational as well as technological constraints. Everyone played this game. As the minister of the aircraft industry later explained in February 1941, "Work on the creation of jet propulsion engines at home in the USSR . . began on the initiative of a few engineers taking the form of inventors' proposals." their sponsor in the soldier Tukhachevskii, whose personal plan seems to have been to build exclusive links with them and try to monopolize new technologies in artillery and aviation for the Army (Siddiqi 2000a: 4-7). Some of them paid a heavy price for this private connection in 1937, when Tukhachevskii was arrested and executed as a spy. The steam engineers eventually found their patron in Industry, under the aircraft industry leader Mikhail Kaganovich, who later mentioned how it came about: "Three years ago comrade Tsvetkov came to me and proposed making such a turbine, I went to the boss, the people's commissar signed a decree to the effect that, in urgent order, under personal responsibility,

${ }^{16}$ RGAE, 8044/1/460: 59 (minister Shakhurin to deputy prime minister Voznesenskii, February 5, 1941) 
[inaudible] to build a turbine." ${ }^{\prime 17}$ Liul'ka, father of the Soviet turbojet, started his work in 1936 on the back of a steam turbine project in Khar'kov, but managed to attract independent funding only after a three-year struggle with the authorities including a personal encounter in Moscow with minister Kaganovich and a written petition to prime minister Molotov (Berne and Perov 1998: 78-81). Kaganovich was a second-rate patron; despite his much more famous brother Lazar, one of Stalin's closest associates, Mikhail lacked clout and his ministerial career ended in failure in 1940. After Tukhachevskii's execution in 1937, therefore, the cause of aviation jet propulsion lacked a powerful sponsor until Stalin's deputy Georgii Malenkov began to take an interest in $1943 .{ }^{18}$ This was a timely move since both German and British inventions were about to materialize in the skies above Europe.

One consequence of the designers' initiative was that projects tended to proliferate beyond intended limits, in an uncontrolled way. Designers worked to secure ministerial approval and the funding that followed. If refused at one level, they appealed to the next. If necessary they began work without waiting for authorization; they illegally diverted resources of their own design organizations that had been allocated to other uses and then used the preliminary results to support subsequent attempts to gain official backing. The director of research institute no. 3 outlined the consequences at an internal meeting held in May 1942, when the wartime strain on resources was at its most acute:

As an example of how we are forced to diffuse the attention of our cadres I will take the first research department. There are 26 [research] topics for 10 engineers. Some of these topics are incidental to our institute and do not match its profile or specialization. These topics arose because there were people to put them forward and instead of passing them on to those organizations for whom such topics were more appropriate we engaged in them ourselves. ... It's characteristic of such topics that working on them involves unnecessary investigations since [we have] no corresponding experience. Often what is done is done many times, and all because we took on what was not our business, because we have neither experience nor cadres to work on items that don't match the profile of our institute. ${ }^{19}$

${ }^{17}$ RGAE, 8328/1/824: 35 (August 22 1936). The very first projects in steam propulsion, however, were sponsored by military design organizations, including one under Tukhachevskii's direct control at the time.

${ }^{18}$ For Malenkov's briefing by aircraft industry minister Shakhurin see RGAE, 8044/1/984: 264-275 (October 22, 1943).

${ }^{19}$ RGAE, 8162/1/574: 101 (Kostikov, director of research institute no. 3 of the ammunition industry, formerly the jet propulsion research institute, May 7 , 1942). 
Finally, designers monitored the foreign military and technical press. When they found evidence of aerospace experimentation in rival states, they worked it up so as to demonstrate the advances being made elsewhere, contrast it unfavorably with the state of affairs at home, and promote their own bids for funding. ${ }^{20}$ Conversely, when foreign press information became sparse, they used its disappearance to call urgently for increased funding on the grounds that foreign powers were evidently forging ahead of the Soviet Union in secret. ${ }^{21}$ There is no indication in the aeroengine designers' files that they gained any information about progress in jet engines or rocketry in other countries that was not freely available in the press. If Soviet spies did acquire such information, it did not reach the designers.

\section{Not Knowing When to Stop}

To summarize: the authorities had no difficulty eliciting proposals to start up research. Since there were many projects to fund, they funded them in instalments. At the start of a project the officials usually had little more than an engineer with some qualifications and letters of personal recommendation who could talk at them knowledgeably and with enthusiasm about matters beyond their experience. By limiting start-up funding and making further instalments conditional upon progress reports, they could increase their information about the quality of projects beyond that which was available initially. ${ }^{22}$ The time for approving the next instalment became an opportunity to review each project, evaluate its results so far, and decide whether to continue or discontinue funding. The evidence suggests, however, that the authorities did not normally have a good idea of when to stop. Rather, funding decisions were reactive; the fact that a project had been previously approved so that initial funds had been disbursed and work begun was a sufficient reason, other things being equal, for funding to be continued.

There are two possible reasons for this, one political and the other economic. The political mechanism would work as follows. In every political system there are channels that allow resources to be exchanged for loyalty. Possibly, military

${ }^{20}$ For examples, RGVA, 34272/1/105: 91-94ob (May 20, 1931) and 118-120 (May 1931; RGAE, 7516/1/324, 1-4 (April 9, 1939); RGAE, 8162/1/305, 30 (April 16, 1940).

${ }^{21}$ RGAE, 8159/1/149: 220 (July 26, 1936), 219 (September 29, 1936) and 218 (October 13, 1936); RGAE, 7516/1/324: 10 (no date but 1939).

${ }^{22}$ For annual reports of the jet propulsion research institute and its successor organization for 1936, 1939, and 1940, for example, see RGAE, 8159/1/137: 2-28 (no date but 1937), 8162/1/240: 9-63 (January 9, 1940), and 8162/1/449: 2-61 (January 14, 1941) respectively. The annual reports for 1937 and 1938 were removed from the archive in the 1960s, apparently on the instruction of the USSR Academy of Sciences, and have not been traced. 
research was one such channel in the Soviet system. The rocket scientists that Tukhachevskii patronized, for example, clearly developed loyal feelings toward to him; did he fund their work because he wanted their inventions, or because he wanted their loyalty, now or in the future? If the latter, then in this case the market for inventions was primarily a political market in which loyalty was the desired final product and inventions were an incidental by-product.

The alternative is that the funding authorities actually wanted technological results and were relatively uninterested in the personal loyalties of the technologists. Why then did they appear ready to roll funding over from year to year, even when progress was slow or non-existent? Possibly, because they were rationally unable to enforce the strict success criteria that they demanded initially. The reasoning of Mathias Dewatripont and Eric Maskin (1995) suggests the following example; to keep it simple, the discount rate is zero.

Year 0. A project is expected to cost 100,000 rubles a year and last two years, so its total cost should be 200,000 rubles. Its result will be worth 1 million rubles if it succeeds, and the funding authority estimates its chance of success at $25 \%$, giving an expected value of 250,000 rubles and a surplus over costs of 50,000. The project is approved for two years. If the project's expected duration were 3 years, however, implying a total cost of 300,000, a loss would be expected and the idea would be rejected.

Year 2. Two years have passed and the 200,000 has been spent with no result. Should the funder close the project down or let it continue? The designers ask for another year and another 100,000; they say they can still obtain the desired result. The funder, now more skeptical, revises the project's chance of success down to $20 \%$, say, so its expected value has fallen to 200,000 . But this expected value of 200,000 is now available for an outlay of only 100,000 , leaving a surplus equal to 100,000 , which is more than before! The funder will approve the project for another year, or lose the expected surplus.

It is true that after the extra year the total outlay of 300,000 will have exceeded the expected value of the project; if the funder had known this beforehand, the project would never have been allowed to start. But the first 200,000 is a "sunk cost"; it is gone beyond recall. Because it is gone, it should no longer enter into the funder's calculation; two years having gone by, only the marginal cost of the third year remains relevant. In short, once the first instalment has been paid and has become a sunk cost, the payment of the next instalment becomes more likely. Projects can win continued funding even after it is known that they should never have been started.

The evidence from the Soviet market for military inventions, although not entirely straightforward, allows us to rule out the political mechanism in most cases. If the main motive for funding projects was to win the agent's loyalty, it is necessary that the principal should have signalled this, because there had to be a way of letting the agent know that the funding was more than what any objective social planner would have provided; otherwise, why should the agent offer loyalty in exchange? We can imagine the sort of ceremonial that would have welcomed success and excused failure alike: ministers would have made speeches emphasizing the common goals, the difficulties of the task, the comradeship of the 
struggle, the great efforts made, the experience gained, the foundations laid, the possibilities of future progress, and the valuable spin-offs generated along the way.

The evidence does not match this at all. When faced with a lack of results, ministers did not excuse failure but became impatient and bullying. Kaganovich accused the steam turbine engineers of losing touch with reality, and mocked them for confusing aviation with railroads: "You could put a F[eliks] $\mathrm{D}$ [zerzhinskii] locomotive in an aircraft, but then the aircraft would weigh 2,000 tons. This is comrade B[inaudible]'s fantasy, he's got 245-meter wings and a 45meter fuselage ... We're not talking about a boiler on a Tsvetkov locomotive [Tsvetkov was a turbine specialist] . . . if we put an airscrew on a locomotive it'll turn, but we need to put it in an aircraft at altitude . . I can't sit for three years and see no results." ${ }^{, 3}$ As the evidence of failure mounted the engineers pleaded the value of potential spinoffs from their work on aviation for naval and locomotive engineering, to no avail (Rodionov 2005, under January 15, 1938).

It is possible that Stalin had favorites and this gave them some limited protection. Gennadii Serov (1997: 4) has suggested that Stalin favored the rocket designer Andrei Kostikov with disproportionate funding. In November 1942 Stalin authorized an unproven Kostikov design, the 302 rocket fighter, for development at a time when other new initiatives were being ruthlessly subordinated to the mass production of existing lines. When the 302 proved a failure Kostikov was sacked, then arrested, but released a year later, and he was allowed to retain his military rank and decorations. Korolev's biographer Iaroslav Golovanov (1994: 511) claims that "Stalin needed Kostikov, since [the latter] was one of the bearers of the Stalinist world order." Stalin was habitually suspicious of those he favored, however. In 1950, for example, he suddenly accused the aircraft designer Iakovlev (2000: 395) of diverting state funds into excessive salary and bonus payments: "Do you know what they say about you behind your back? They tell me you're a thief." What saved Iakovlev was the support of his boss, minister of the aircraft industry Khrunichev, who proved to Stalin that Iakovlev's design team and production workers were fewer in number, lower paid, and less well equipped than those of the other designers.

In short, the funding of research proceeded generally on the basis that the authorities wanted results, not loyalty. In the presence of sunk costs, however, there were no clear rules for defining failure or terminating failed projects. In the absence of rules the authorities tended to roll funding over from year to year until their patience suddenly ran out; then, the money stopped and heads rolled.

In the case of rocket research at the jet propulsion research institute, for example, frustration boiled over in the context of the Great Terror. ${ }^{24}$

${ }^{23}$ RGAE, 8328/1/824: 12, 15, and 52 (August 22, 1936).

${ }^{24}$ For recent studies of the rocket scientists' purge see Harrison (2000: 12830) and Siddiqi (2000: 10-11). The aircraft industry yields a number of design organizations that were closed because of a lack of results. Bartini, Grigorovich, Miasyshchev, Petliakov, Polikarpov, Sukhoi, and Tupolev are all cases of chief 
Tukhachevskii was arrested in May 1937. The purge of the rocket scientists began in October with arrests including the director and the rocket motor specialist Glushko. In June 1938 work on the Korolev-Glushko rocket aircraft project was suspended on the grounds that it was diverting funds away from work of more immediate military utility such as rocket artillery; Korolev was arrested, charged with being a Trotskyist saboteur, and sentenced to ten years' forced labor.

Another rocket establishment was closed down in the following way. Tukhachevskii had set up military design bureau no. 7 (KB-7) in 1935 to promote rocket aviation. In January 1938, with Tukhachevskii gone, the design bureau was transferred from the Army to Industry, handed over to the ministry of the defense industry's chief administration for ammunition. But design bureau no. 7 never produced any results; its annual report for 1938 says, for example: "for armament in 1938 nothing supplied, in view of the long-term (perspektivnyi) character of work." ${ }^{25}$ Then, in early 1939 the Red Army and Navy decided unilaterally to stop funding 47.5 million rubles' worth of research and experimentation out of 77.5 million previously agreed with the ammunition industry; this left design bureau no. 7 entirely with funding. ${ }^{26}$ The bureau was closed down before the end of the year; according to Siddiqi (2003) it imploded with the staff denouncing each other and the director who was arrested and imprisoned.

To summarize: the funding authorities were vulnerable to a failure of commitment: before the event, they intended to fund only good projects and were ready to discontinue the funding of bad ones, but after the event it was harder than expected to carry out their intention, and low- or no-return projects continued to squeeze the funding of those that would eventually bear fruit.

In retrospect the surprise is that the Soviet market for inventions worked as well as it did. Research and development is, first and foremost, a forward-looking activity. No one would undertake it that did not have a long time horizon or was unwilling to wait patiently for results. Of next importance, $R \& D$ contracts normally involve a complicated sequence of immediate advances by the funder in the expectation of future results from the designer; normally, they also allow for sharing risks of success and failure proportionally between the two sides. One might expect, therefore, that R\&D would work best within stable rules so that each side could make clear long-term commitments, confident in the expectation that the commitments made by the other side would be fulfilled. Yet this is not what we see.

designers imprisoned along with their teams; Kalinin was executed (Albrecht 1989: 133-36 and 214-15). The same happened in other lines of work; those charged with designing the Soviet Union's first atomic bomb, for example, expected medals if it worked, and imprisonment or execution if it didn't (Holloway 1994: 215).

${ }^{25}$ RGAE, 8162/1/89, 125 (no date but 1939).

${ }^{26}$ RGAE, 8162/1/299: 36-54 (reports to Sergeev, forwarded by him to Kulik, Frinovskii, and Molotov, March to April 1939). 
The Soviet market for inventions was chaotic. It was driven by the designers, who did not form a quiet orderly line for funding but joined an unruly mob that pestered officials without mercy and ruthlessly jostled each other out of the competition. Once in the market many designers obtained some financial returns to their efforts, but the rewards seem to have borne little relationship to results. The designers also incurred non-trivial personal risks, dressed up as punishment for failure, but the criteria for penalization, including the time horizon over which they were judged to have failed, were fixed arbitrarily and revised without warning. The lack of rules, not particularly surprising in itself, was the product of a harsh dictatorship that ruled by decree in all areas of economic life. Despite this, the Soviet market for inventions succeeded in the sense that it gave rise to a stream of excellent designs that kept the Red Army close to the world militarytechnical frontier. In short, chaos did not frustrate intentions.

It is possible that the lack of rules helped the authorities to mitigate the problem of adverse selection. Adverse selection arose when there were two types of project, good and bad. The funding authorities, unable to tell them apart, had to offer the same funding to both types. This would have made research and design a safe occupation for the misguided, the talentless, and the time-servers, while squeezing the funding available for the truly talented. Hence the risk that bad projects would drive out the good ones.

The authorities' interventions changed the incentives by turning research and design into a dangerous activity. It was not exactly that they punished failure; they clearly tried to, but failure was something for which they had no clear definition. As a result those who were swept up in purges, arrested, and jailed, included some like Korolev and Tupolev who were ultimately successful and became iconic figures of postwar Soviet technology. In other words, Stalinist repressions made $\mathrm{R} \& \mathrm{D}$ more dangerous for everyone, talented and untalented, alike. The result may have been to deter some of the untalented but risk-averse designers from promoting bad projects; at the same time the truly talented designers were not deterred because they were more driven from within; they were more willing to undertake risks, or were more confident of achieving final success, or both.

What made the great designers great is that they just wanted to build aircraft and jets and rockets and they would attempt to overcome any obstacle to do so. They did not want a quiet life. This motivation could survive years of frustration and poor conditions including, for some, moral and physical abuse, imprisonment, and forced labor. Thus Stalin's terror tried their mettle and proved their comparative worth in ways that more orthodox tests could not. 
Figure 8.1. Dictator, Army, Industry, and Design Organizations: Funding Flows

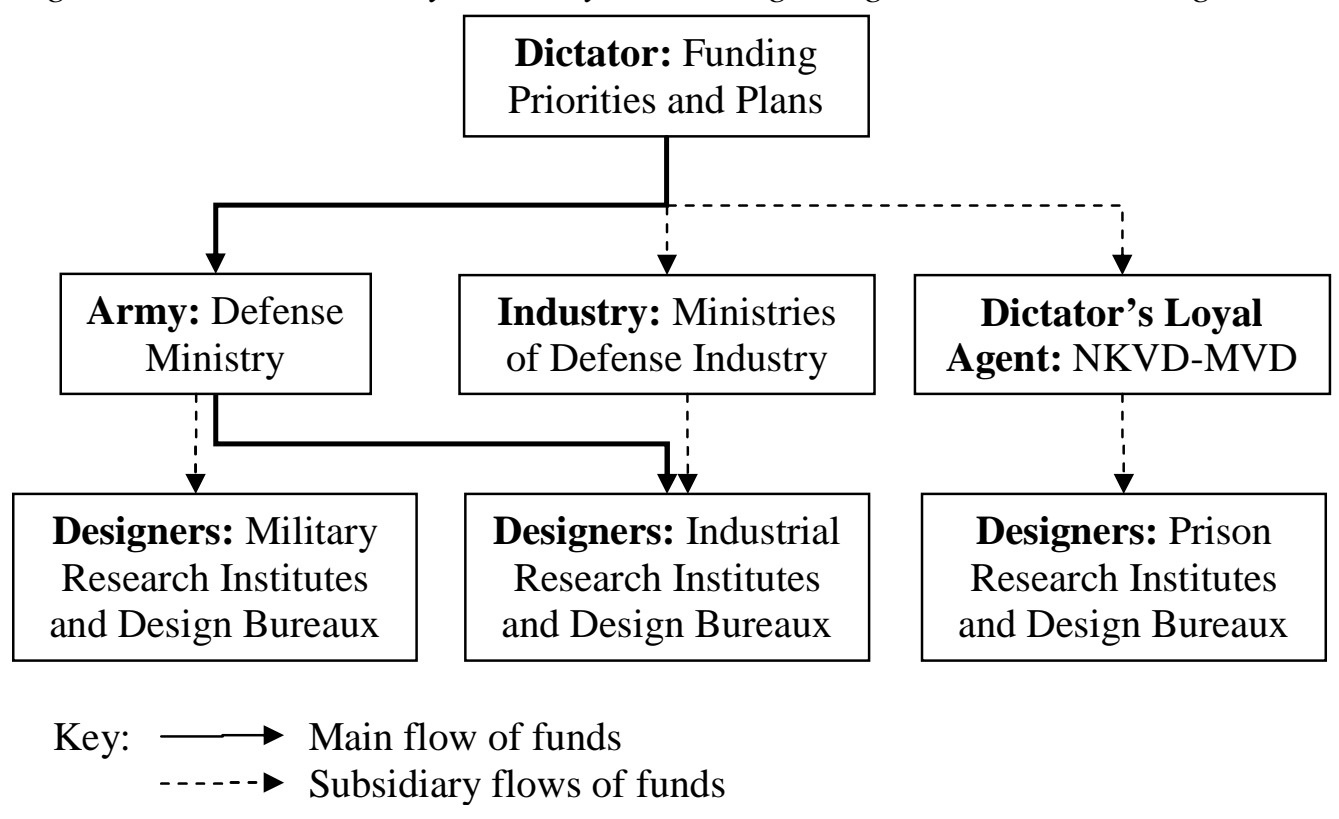


Figure 8.2. Experimental Soviet Rockets and Gas and Steam Turbine Aeroengines, 1932 to 1946: Cumulative Investment in Major Project-Years

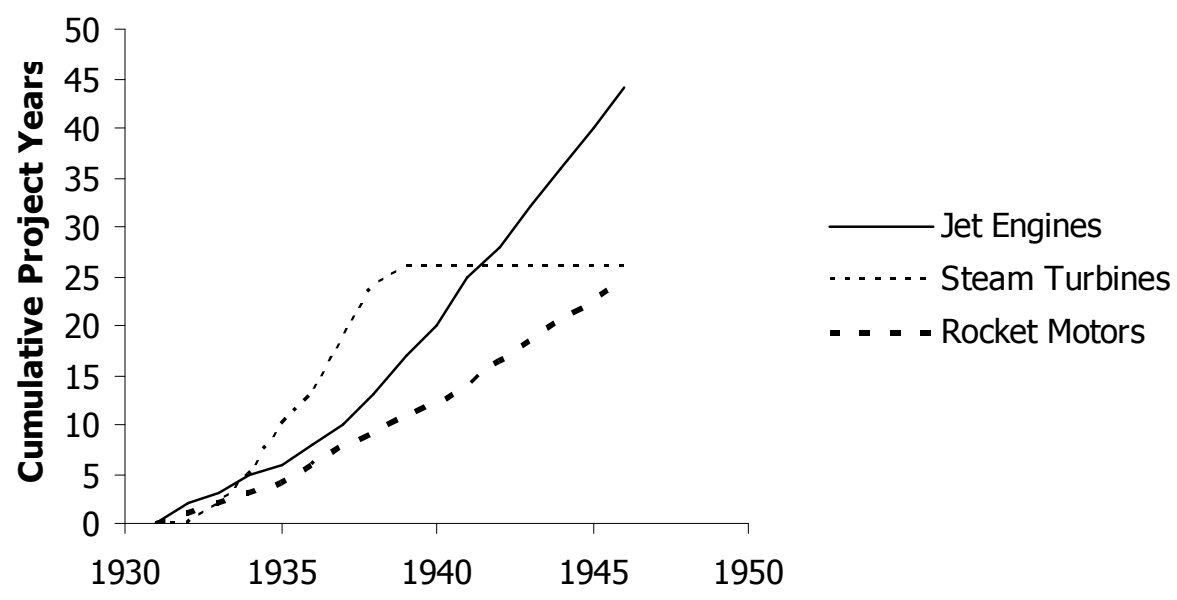

Source: Steam turbines: Harrison (2003); Jets and Rockets: Harrison (2005). 
Figure 8.3. Experimental Soviet Rockets and Gas and Steam Turbine Aeroengines, 1932 to 1946: Major Projects, Total

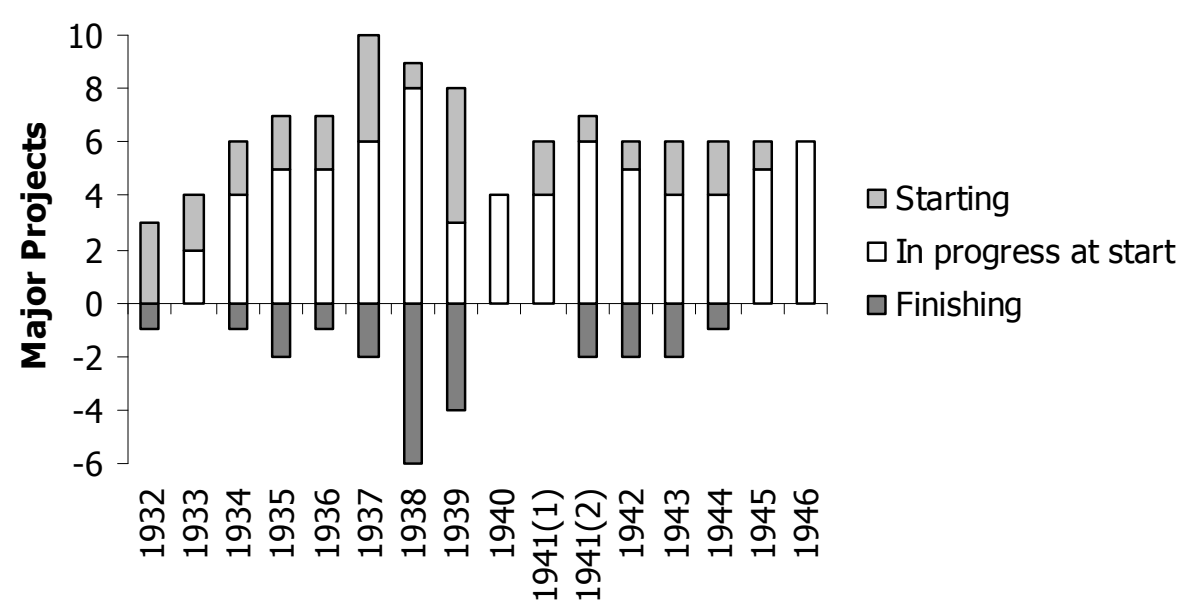

Source: as Figure 8.2. 


\section{Published References}

Akerlof, George A. 1970. "The Market for 'Lemons': Quality, Uncertainty, and the Market Mechanism." Quarterly Journal of Economics 84(3): 488-500.

Albrecht, Ulrich. 1993. The Soviet Armaments Industry. Chur (Switzerland): Harwood Academic Publishers.

Berne, L. P., and V. I. Perov. 1998. "Istoriia sozdaniia pervogo otechestvennogo turboreaktivnogo dvigatelia (K 90-letiiu so dnia rozhdeniia A. M. Liul'ki)." in Iz istoriia aviatsii i kosmonavtiki, vol. 72: 77-94. Moscow: Institut istorii estestvoznanii i tekhniki RAN.

Danilov, B. 1981. "Iz istorii sozdaniia reaktivnoi aviatsii." Voenno-istoricheskii zhurnal, 1981(3): 70-75.

Davies, R. W., and Mark Harrison. 1997. "The Soviet Military-Economic Effort under the Second Five-Year Plan (1933-1937)." Europe-Asia Studies 49(3): 369-406.

Dewatripont, Mathias, and Eric Maskin. 1995. "Credit and Efficiency in Centralized and Decentralized Economies." Review of Economic Studies 62(4): 541-55.

Filtzer, Don. 2002. Soviet Workers and Late Stalinism: Labour and the Restoration of the Stalinist System after World War II. Cambridge, England: Cambridge University Press.

Golovanov, Iaroslav. 1994. Korolev. Fakty i mify. Moscow: Nauka.

Harrison, Mark. 2000. "New Postwar Branches (1): Rocketry." In The Soviet Defence-Industry Complex from Stalin to Khrushchev: 118-49. Edited by John Barber and Mark Harrison. Basingstoke (England): Macmillan.

Harrison, Mark. 2003. "The Political Economy of a Soviet Military R\&D Failure: Steam Power for Aviation, 1932 to 1939.” Journal of Economic History 63(1): 178-212.

Harrison, Mark. 2005. "A Soviet Quasi-Market for Inventions: Jet Propulsion, 1932 to 1946." Research in Economic History 23: 1-59.

Holloway, David. 1982. "Innovation in the Defence Sector" and "Innovation in the Defence Sector: Battle Tanks and ICBMs." In Industrial Innovation in the Soviet Union: 276-414. Edited by Ronald Amann and Julian Cooper. New Haven, CT: Yale University Press.

Holloway, David. 1984. Stalin and the Bomb: the Soviet Union and Atomic Energy, 1939-1956. New Haven, CT: Yale University Press

Iakovlev, A. S. 2000. Tsel' zhizni. Zapiski aviakonstruktora, 6th edn. Moscow: Respublika.

Knörnschild, E. 1941. "Dampftriebwerke für Flugzeuge.” Luftwissen 8(12): 36673.

MacKenzie, Donald. 1996. Knowing Machines. Cambridge MA: MIT Press.

Mokyr, Joel. 1990. The Lever of Riches: Technological Creativity and Economic Progress. Oxford: Oxford University Press.

Mukhin, Mikhail. 2004a. Aviaprom. Sovetskaia aviapromyshlennost' v 1921$1941 \mathrm{gg}$. MS in preparation. 
Mukhin, Mikhail. 2004b. "Employment in the Soviet Aircraft Industry, 1918 to 1940: Work Culture, Organization, and Incentives." PERSA Working Paper no. 36. University of Warwick, Department of Economics. Internet address: http://www.warwick.ac.uk/go/persa.

Ordway, Frederick I., and Mitchell R. Sharpe. 1979. The Rocket Team. London: Heinemann.

Rodionov, Ivan. 2005. The Aviation and Aircraft Industry of the Soviet Union, 1916 to 1946, Version 5, University of Warwick, Department of Economics, available at http://www.warwick.ac.uk/go/aviaprom.

Serov, Gennadii. 1997. "V nachale reaktivnoi ery." Samolety mira, 1997(3-4): 27.

Siddiqi, Asif A. 2000. Challenge to Apollo: The Soviet Union and the Space Race, 1945-1974. Washington, DC: NASA History Division (NASA SP2000-4408).

Siddiqi, Asif A. 2003. "The Rockets' Red Glare: Technology, Conflict, and Terror in the Soviet Union." Technology and Culture 44(3): 470-501.

Smith, G. Geoffrey. No date. Gas Turbines and Jet Propulsion for Aircraft. London: Flight Publishing Co.

Starkov, Boris. 2000. "The Security Organs and the Defence-Industry Complex." In The Soviet Defence-Industry Complex from Stalin to Khrushchev: 246-68. Edited by John Barber and Mark Harrison. Basingstoke (England): Macmillan. 